\title{
実験小動物（マウス）の体力判定法 \\ Determinating Method of Physical Strength for Small Animals (Mice)
}

\author{
横浜医科大学衞生学教室 (主任 萩原兼文教授) \\ 都筑弘・大川一義・細 谷孝 \\ Hiroshi Tsuzuki, Kazuyoshi Ôkawa, Takashi Hosoya \\ Department of Hygiene, Yokohama Medical College
}

(Director: Prof. K. Hagiwara)

\section{1. まえがき}

衞生学の領域でも生物学的実験を扎てなう.に際しては 種々の小動物を使用する。そして血液・尿などを用いて の生化学的分析実験や, 死後梞たは屠殺後に臟器組織索 用いての組織学的ないし病理学的検索が抢こなわれる。 また，いろいろな環境因子の変化・工業的毒物による中 毒・栄養またはビタミン障害なざによつて招来される生 体反応としても生化学的または組織化学的分析を主とす るととが多い。一個の生体としての全般汶対する全身的 影響の観察恃体重の変化または下肢長・長骨長・尾長な ぞ形態学的計測が多くおてなわれる。しかしながら，上 記のごとき種々の生活環境因子・条件が生体に及汭した 結果を判断するときに形態学的計測観察の久でよいか否 かは疑問であるし，わずかの作用因子・作用条件が相当 長期間にわたつて連続的に働くときに，とくに小動物で は形態学的計測値の差が僅小で明確に判断することが困 難な場合むあり，また全身機能的な差異を判断すること によつて作用因子・作用条件の影響を確認するととも必 要であると考えられる。

身体機能の測定を扣しなうとして，なにぶん意志力を もたない小動物のととであり，一定の運動を継続的に掠 こなわしめるには困難を伴ならことが多い。全身または 体の一部分を必ず動かし続けね就ならぬような状態に陥 らしめることによつて, 体力保持能力・生命力の時間的 長さを測定するととができれば,打打をね所期の目的(身 体的機能一一体力）を充分ならずとも満たすととができ ると考えられ，種々の実験に供した動物（マウス）を水 中に遊泳せしめて溺死する宋での所要時間 (遊泳時間) を計測するととを案出した。水中での遊泳は心・肺・筋
の全身的機能の総合的な働きを要するものであるから， いわゆる全身的体力のいかんを判定する方法としては簡 易にしてかつ完辝汇近いものと考えられる。

\section{2. 遊泳装置と水温}

マウスの水中遊泳時間の長短によつて体力を判定する ことはすでに大川が案出公表したものであるが，その後 さらに遊泳装置についてやや再検討を加え，マウスの遊 泳中の水温を恒定せしめるよ5簡易装置を試作した。

\section{第 1 図 マウス游泳時間測定装鼍略図}

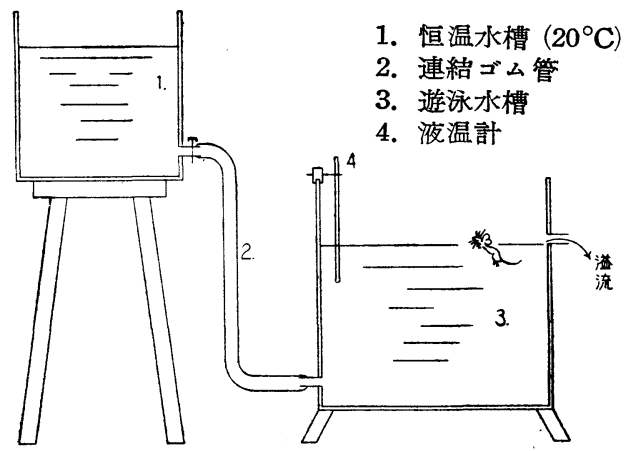

遊泳至適水温の決定は困難な問題で, 本来の目的が遊 泳させるのではなしに溺死させるのであるから, 長時間 遊泳生存して捛つたのではかえつて判定実施泪るし， 逆に数分という短時間のうちに溺死してしまうのもまた 遊泳時間の差学求めるのに困難で，数十分加 $2 \sim 3$ 時 間位までの範囲で溺死すれば実施にも便宜であるし時間 差を求めるにも容易であろらと考えられた。かかる点か らすでに大川は判定のための至適水温を $20^{\circ} \mathrm{C}$ と決定して 実施したのであるが，比較の便のために水温 $25^{\circ} \mathrm{C}$ 抢よび 
$15^{\circ} \mathrm{C}$ の場合の遊泳時間の実験結果を提示するとととす る。

\section{第 2 図}

1. 水温 $25^{\circ} \mathrm{C}$
体重 $7.5 \sim 10.5 \mathrm{~g}$ 平均 $9.3 \mathrm{~g}$
(24例)
体重 $11.0 \sim 20.0 \mathrm{~g}$
遊泳時間 $362 \sim 498$ 分 平均 424 分
(24例)

2. 水温 $15^{\circ} \mathrm{C}$

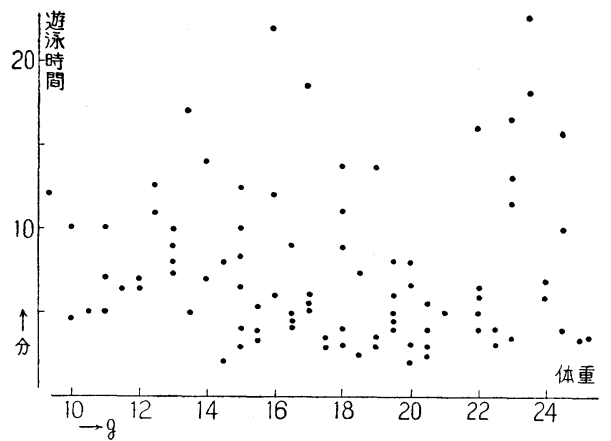

第 3 図 水温 $20^{\circ} \mathrm{C}$

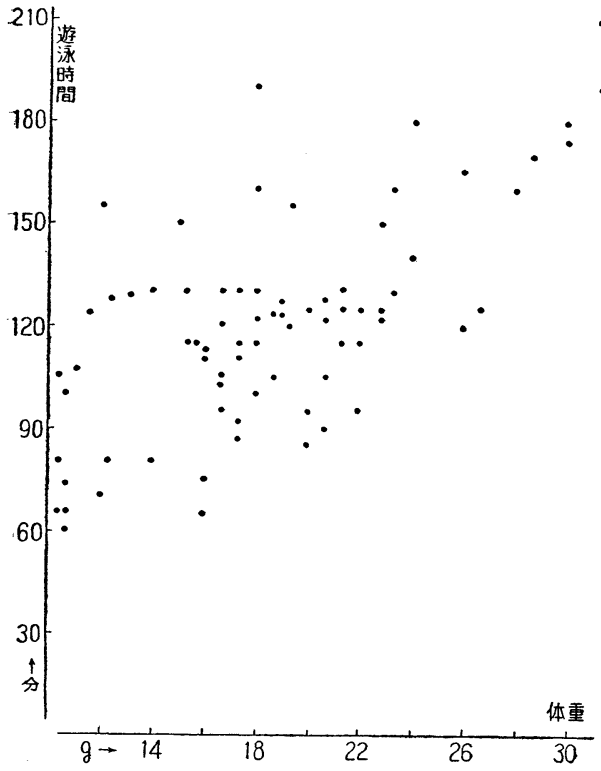

第 2 図によつて明らかなどとく，水温 $25^{\circ} \mathrm{C}$ の際に汁体 重 8〜10gの幼若マウスで 270〜 320分を示し, 体重11 gを超えるマウスでは 360 分以上も遊泳李続付る。した がつて半日 から長いものでは終日泳ぎ続讨るととにな
り，実験実施仗支障をきたすととがある。とれに反して 水温 $15^{\circ} \mathrm{C}$ 際には遊泳時間は全般的にきわめて短く，体 重24gのマウスでも最長20分でかつ体重の大きさのいか ん汇拘らず短時間内に溺死するので体重との関連性およ び時間に表わされる体力差が失われてしまう。

第 3 図汇反るごとく，水温 $20^{\circ} \mathrm{C}$ 際汇体重 $10 \mathrm{~g}$ 加 $30 \mathrm{~g}$ の範囲て遊泳時間は60分から 210 分の範囲となり, しかも扮扮壳㸚体重と遊泳時間とが正の相関をなすバラ ツキを示した。

したがつて，計測実施の容易さと個体差判定の容易さ とから，水温は $20^{\circ} \mathrm{C} か ゙$ 最適であると考えられる。

\section{3. 遊泳時間（すなわち体力）の比較}

すでに大川はその原著の中でセレニウム中毒マウスが 健常マウスに比して遊泳時間が劣弱化しているととを証 明し，水中遊泳がマウスの体力判定に役立つととを確認 しているが，セレニウムとよる慢性的中毒群と白米のみ で飼育した偏食群とについて遊泳時間の比較検討をおこ なつた。

罒によつて明らかなどとく，七レニウム中毒群では全 般的に遊泳時間が短縮して扣り，セレニウムの体内摄取 量・被曝露時間と期間・抵抗性など種々の問題があろろ 乙考元られるが全般的な遊泳時間短縮亡体重・遊泳時間 相関の乱れこが明示されている。

偏食群（白米のみで飼育）では同様汇全般的な遊泳時

第 4 図 セレニウム中毒群（水温 $20^{\circ} \mathrm{C}$ ）

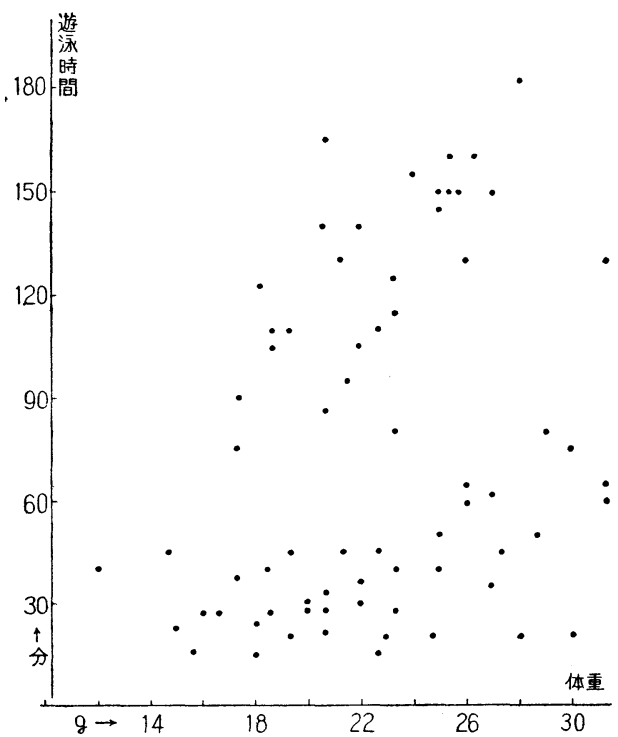


第 $\mathbf{5}$ 図 偏食群（水温 $20^{\circ} \mathrm{C}$ )

(白米のみで飼育 3 週後)

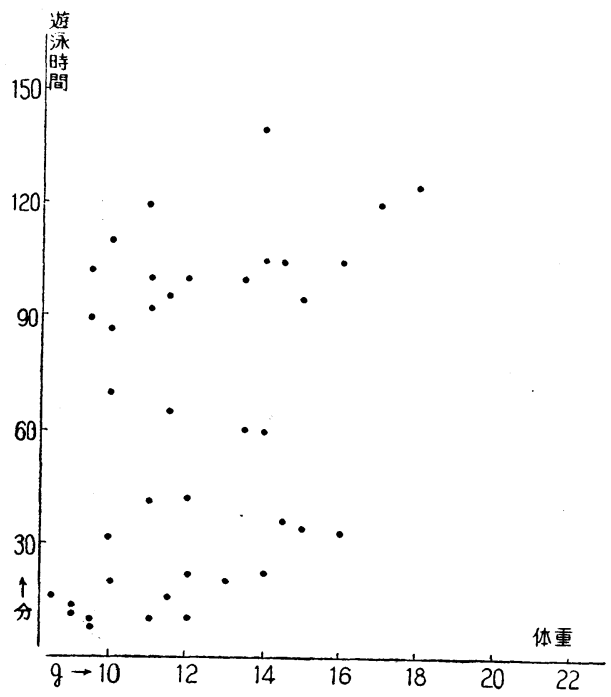

間短縮がかなり著明である。との偏食群では初めに体重 $10 \mathrm{~g}$ 前後のむのから飼育して 3 週を経過してもな打体重 増加が少なく，したがつて体重 $18 \mathrm{~g}$ を超えるマウスにつ
いと検測することができなかつた。通常飼育では体重10 $g$ 前後で 3 週後には $20 \mathrm{~g}$ 前後汇達するのが常であるから 偏食なるが故の体重增加不良と考方ら㣗るが，との点仁 関しては本実験の主旨からそれるので検討を避け灷。な お体重之遊泳時間との相関性法健常群（第 3 図）绖ど明 確婊われていない。

したがつて，広義の環境因子がその作用機序はともか くとして明らかに実験動物の水中遊泳時間の長さで表示 される全身的機能に障害を及济すととが知られる。

\section{4. 結 語}

すでそ大川がその原著に述べたごとく，衛生学領域で の動物を用いての実験で，種々な作用因子・作用条件が 招来する影響・結果の全身的機能（体力）判定するた わの 1 方法として, マウスに执いて水温 $20^{\circ} \mathrm{C}$ の亿遊泳 坑しわて溺死する去での時間（遊泳時間）を正確汇計測 することが良法であることを確認し，とれに要する簡便 な装置索考案試作した。

\section{交献}

大川一義 : 日本衞生学雑誌 13 : (5), 577, 1958. (受付 : 1959年 3 月 24 日, 特別掲載) 